\title{
Lived Experiences of Students in Remote Area in The New Normal
}

\author{
Virginia S. Ariza, Ph. D $^{1 *}$, Junelle S. Ariza, LPT ${ }^{2}$
}

\author{
${ }^{1}$ Head, Research and Development Office, \\ Eastern Visayas State University, Barugohay Norte Carigara, Leyte \\ ${ }^{2}$ Gregorio Catenza National High School, Tunga, Leyte \\ *Corresponding author details: Virginia S. Ariza; virginia.ariza@evsu.edu.ph
}

\begin{abstract}
Due to the Coronavirus Disease 2019 (COVID-19) Pandemic face-to- face classes were prohibited. However, the Department of Education (DepEd) believes that education shall continue so they implemented alternative learning delivery modalities such as Modular Distance Learning. This new normal has brought a lot of challenges to students, especially those from remotes areas, which has affected their academic performance. In order to understand the experiences of students in remote areas in the new normal, this study was conducted to describe their lived experiences, the issues and challenges they encountered in modular distance learning and their coping mechanism. The participants of this study were the 9 Grade 8 Students of Gregorio C. Catenza National High School who were from Barangay Burabod, Jaro, Leyte. This study used descriptive phenomenological approach as its research design. The participants underwent in-depth one-on-one interview about their experiences in the new normal. The thematic analysis was used to determine significant themes from the participants' responses. Five distinct themes emerged from the research data. The major themes identified from the results of this study included: learning is difficult; poor learning outcome; Socio-Economic Status and Unavailability of Learning Resources; More Knowledgeable Other; and Social Network and TimeManagement. This result indicates that students in the remote areas encountered difficulties in the new normal.
\end{abstract}

Keywords: students' lived experiences; issues and challenges; remote area; new normal

\section{INTRODUCTION}

The Corona Virus Disease - 19 (COVID-19) pandemic is a social and an economic crisis just as much as it is a health one - its repercussions, severe and far-reaching, are being felt across the world. From school closures to devastated industries and millions of jobs lost - the social and economic costs of the pandemic are many and varied. COVID-19 is threatening to widen inequalities everywhere, undermine progress on global poverty and clean energy, and more (wellcome.org).

However, the Department of Education (DepEd) believes that education shall continue despite the situation so they implemented the Basic Education Learning Continuity Plan (BE-LCP) for the Academic year 2020-2021. BE-LCP is a package of education interventions that will respond to basic education challenges brought about by COVID-19 (DepEd Order No. 12, 2020). In order to protect the health, safety, and well-being of learners, teachers, and personnel, and prevent the further transmission of COVID19, the department implemented the alternative learning delivery modalities such as modular, television-based, radio-based instruction, blended, and online while face-to-face classes still prohibited due to the public health situation (De Villa, et. al., 2020). Face to face learning engagement of students and teachers within the school has been suspended due to the COVID-19 pandemic. This pandemic has paved the way to the implementation of Modular Distance Learning as an urgent response to ensure continuity of education (Dangle, Sumaoang, 2020). In the implementation of the modular distance learning, teacher takes the responsibility of monitoring the progress of the learners. The learners may ask assistance from the teacher vie e-mail, telephone, text message/instant messaging among others (Dangle, Sumaoang, 2020). In addition, limited contact with teachers will place parents or guardians as the learners' model or the "More Knowledgeable Other" (MKO).

However, parents and guardians will face various challenges in fulfilling their roles as MKOs. The first challenge lies in the fact that parents and guardians have varying skills, knowledge, and qualifications. Existing research also shows the interconnectedness of parents' educational level and their income. Another challenge pertains to children's ability to learn by imitation. In his Social Learning Theory, behaviorist Albert Bandura says that learners learn by imitation, observation, and modelling. With parents as the primary models of learners, their attitudes, specific beliefs, thoughts, and feelings-cognitive biases-may affect each learner's learning process. It may be intentionally or unintentionally shown or taught by the MKOs, depending on their understanding of a particular lesson or subject matter. The final challenge of learning falls under children having preferred MKOs. They choose who will assist them with their lessons and assignments, depending on their attachment with that MKO. All these are the challenges posed by the differences of MKOs in terms of expertise, educational attainment, cognitive biases, and even emotional connection to the learner (Manlangit, et. al., 2020). Meanwhile, according to the study of Janet Owens et. al. (2009), while there has been research into the provision of 'distance' and 'off-campus' education, both in relation to technology and to curriculum, little attention has been given to the experiences of students studying in geographically remote locations. 
The researchers are public school teachers, they earnestly feel the difficulties of the students in modular learning most especially those in remote areas with poor internet connectivity, having less access to learning resources and in poor socio-economic status who cannot afford to buy teaching-learning latest gadgets. Apparently, these students find it difficult to comply and complete their learning modules. Moreover, despite home visits conducted by the researchers to students residing in the remote area, they noticed that their learning modules are submitted unfinished or worse left unanswered. These could impact adversely the students learning and academic performance. In connection with the above mentioned, this study aimed to describe the lived experiences of students in the remote areas where internet and/or learning resources are not readily available in this new normal education. The results of this study will be used to formulate recommendations that could address the situations of the students from remote areas in the new normal education.

\section{METHODOLOGY}

This study used descriptive phenomenological approach This study was conducted in Barangay Burabod, Jaro, Leyte. Burabod is a barangay in the Municipality of Jaro, in the province of Leyte. It is situated at approximately 11.2017 , 124.7388, in the island of Leyte at 180.6 meters or 592.5 feet above mean sea level. It is 25 - 30 minutes motorcycle ride from Gregorio C. Catenza National High School, Tunga, Leyte. and motorcyle or habal-habal is the only means of transportation. Although it has electricity, cellular signal and internet is difficult to access due to its geographical location. Learning materials and facilities are also limited in this area due to economic status of the barangay. This barangay has 7 Grade 7 students, 9 Grade 8 students, 7 Grade 9 students, and 7 Grade 10 students enrolled in Gregorio C. Catenza National High School District of Tunga, Division of Leyte

The participants of this study were the Grade 8 students who live in the remote areas and currently enrolled in Gregorio C. Catenza National High School, Tunga, Leyte. Since there are only nine (9) students who are living in the selected barangay, they were taken all as participants. The data were collected through an in-depth one-on-one interview using researcher-made interview schedule which was translated to waray-waray language and contains open-ended questions which enabled the participants to give answers on their own words. It consists of three parts: Part I -Respondents Profile, Part II - Lived Experiences in terms of Modular Learning, Effects of New Normal Education to their Academic Performance; Issues and Challenges they Encountered and Part III Coping mechanism in the new normal education. To validate the instrument, a pilot study was conducted to 4 students living in Barangay Mag-Aso, Jaro, Leyte, a nearby barangay of Barangay Burabod, Jaro, Leyte. Needed changes and revisions were made in the instrument before it was be utilized in the actual research.

\section{Data Gathering Procedure}

Prior to data gathering, permission was obtained from the principal of the school where the participants are enrolled through a formal request. Then, a letter was sent to the parents seeking permission to allow their child/ren to be the participants of this study. Before the in-depth one-onone interview was conducted, the objectives of the study were explained and assurance was given that results would be treated with utmost confidentiality and anonymity. During the interview necessary protocols were observed to ensure the safety of the researcher and the participants since the research was conducted within the confines of pandemic. Only those who signified their willingness to participate was asked to respond.

\section{Data Analysis}

The data collected was analysed using the thematic data analysis. According to Galanis (2018), thematic analysis is applied to analyse transcript data that emerge from interviews and focus group, and less usually from observations. This method has 6 steps: 1. Familiarisation with the data: involves reading and re-reading the data to become immersed and intimately familiar with its content; 2. Coding: this phase involves generating succinct labels (codes!) that identify important features of the data that might be relevant to answering the research question. It involves coding the entire dataset, and after that, collating all the codes and all relevant data extracts, together for later stages of analysis; 3. Generating initial themes: this phase involves examining the codes and collated data to identify significant broader patterns of meaning (potential themes). It then involves collating data relevant to each candidate theme, so that you can work with the data and review the viability of each candidate theme; 4 . Reviewing themes: this phase involves checking the candidate themes against the dataset, to determine that they tell a convincing story of the data, and one that answers the research question. In this phase, themes are typically refined, which sometimes involves them being split, combined, or discarded. In our TA approach, themes are defined as pattern of shared meaning underpinned by a central concept or idea; 5. Defining and naming themes: this phase involves developing a detailed analysis of each theme, working out the scope and focus of each theme, determining the 'story' of each. It also involves deciding on an informative name for each theme; 6 . Writing up: this final phase involves weaving together the analytic narrative and data extracts, and contextualize the analysis in relation to existing literature (psych.auckland.ac.nz).

\section{RESULTS AND DISCUSSION}

The participants profile included: age, gender, occupation of parents, parents educational attainment, gadget available and other learning resources. All participants are from Barangay Burabod, Jaro, Leyte, and are Grade 8 students enrolled in Gregorio C. Catenza National High School, Tunga, Leyte. The table below illustrates the participant's profile.

TABLE 1: Summary of Participants Profile

\begin{tabular}{|c|c|c|c|l|c|c|}
\hline Participant & Age & Gender & $\begin{array}{c}\text { Occupation of } \\
\text { Parents }\end{array}$ & $\begin{array}{c}\text { Parents } \\
\text { Educational } \\
\text { Attainment }\end{array}$ & $\begin{array}{c}\text { Gadget } \\
\text { Available }\end{array}$ & $\begin{array}{c}\text { Other } \\
\text { Learning } \\
\text { Resources }\end{array}$ \\
\hline 1 & 14 & $\mathrm{~F}$ & Farmers & $\begin{array}{l}\text { Mother: Elementary } \\
\text { Graduate } \\
\text { Father: High School } \\
\text { Graduate }\end{array}$ & $\begin{array}{c}\text { Android } \\
\text { Phone } \\
\text { (Borrowed) }\end{array}$ & None \\
\hline 2 & 14 & $\mathrm{M}$ & $\begin{array}{l}\text { Housewife } \\
\text { Family Driver }\end{array}$ & $\begin{array}{l}\text { Mother: High School } \\
\text { Graduate } \\
\text { Father: High School } \\
\text { Graduate }\end{array}$ & $\begin{array}{c}\text { Android } \\
\text { Phone } \\
\text { (Owned) }\end{array}$ & $\begin{array}{c}\text { TV (News) } \\
\text { Books }\end{array}$ \\
\hline
\end{tabular}




\begin{tabular}{|c|c|c|c|c|c|c|}
\hline Participant & Age & Gender & $\begin{array}{l}\text { Occupation of } \\
\text { Parents }\end{array}$ & $\begin{array}{l}\text { Parents } \\
\text { Educational } \\
\text { Attainment }\end{array}$ & $\begin{array}{c}\text { Gadget } \\
\text { Available }\end{array}$ & $\begin{array}{c}\text { Other } \\
\text { Learning } \\
\text { Resources }\end{array}$ \\
\hline 1 & 14 & $\mathrm{~F}$ & Farmers & $\begin{array}{l}\text { Mother: Elementary } \\
\text { Graduate } \\
\text { Father: High School } \\
\text { Graduate }\end{array}$ & $\begin{array}{l}\text { Android } \\
\text { Phone } \\
\text { (Borrowed) }\end{array}$ & None \\
\hline 2 & 14 & M & $\begin{array}{c}\text { Housewife } \\
\text { Family Driver }\end{array}$ & $\begin{array}{l}\text { Mother: High School } \\
\text { Graduate } \\
\text { Father: High School } \\
\text { Graduate }\end{array}$ & $\begin{array}{l}\text { Android } \\
\text { Phone } \\
\text { (Owned) }\end{array}$ & $\begin{array}{l}\text { TV (News) } \\
\text { Books }\end{array}$ \\
\hline 3 & 15 & M & $\begin{array}{l}\text { Housewife } \\
\text { None }\end{array}$ & $\begin{array}{l}\text { Mother: High School } \\
\text { Graduate } \\
\text { Father: High School } \\
\text { Graduate }\end{array}$ & $\begin{array}{l}\text { Android } \\
\text { Phone } \\
\text { (Owned) }\end{array}$ & $\begin{array}{l}\text { Math Book } \\
\text { TV (News) }\end{array}$ \\
\hline 4 & 13 & $\mathrm{~F}$ & $\begin{array}{l}\text { Housewife } \\
\text { None }\end{array}$ & $\begin{array}{l}\text { Mother: High School } \\
\text { Graduate } \\
\text { Father: High School } \\
\text { Graduate }\end{array}$ & $\begin{array}{l}\text { Android } \\
\text { Phone } \\
\text { (Owned) }\end{array}$ & None \\
\hline 5 & 14 & M & $\begin{array}{l}\text { Construction } \\
\text { Worker } \\
\text { Manicurist }\end{array}$ & $\begin{array}{l}\text { Mother: High School } \\
\text { Graduate } \\
\text { Father: High School } \\
\text { Graduate }\end{array}$ & $\begin{array}{l}\text { Android } \\
\text { Phone } \\
\text { (Borrowed) }\end{array}$ & None \\
\hline 6 & 14 & M & $\begin{array}{c}\text { OFW } \\
\text { Domestic Helper } \\
\text { Bar Tender }\end{array}$ & $\begin{array}{l}\text { Mother: High School } \\
\text { Graduate } \\
\text { Father: College Level }\end{array}$ & $\begin{array}{l}\text { Android } \\
\text { Phone } \\
\text { (Owned) }\end{array}$ & None \\
\hline 7 & 14 & $\mathrm{~F}$ & $\begin{array}{l}\text { Househelp } \\
\text { Farmer } \\
\text { (Coconut wine } \\
\text { Harvester) }\end{array}$ & $\begin{array}{l}\text { Mother: Elementary } \\
\text { Graduate } \\
\text { Father: Elementary } \\
\text { Graduate }\end{array}$ & $\begin{array}{l}\text { Android } \\
\text { Phone } \\
\text { (Borrowed) }\end{array}$ & None \\
\hline 8 & 14 & $\mathrm{~F}$ & $\begin{array}{l}\text { Housewife } \\
\text { Farmer }\end{array}$ & $\begin{array}{l}\text { Mother: High School } \\
\text { Graduate } \\
\text { Father: Elementary } \\
\text { Graduate }\end{array}$ & $\begin{array}{l}\text { Android } \\
\text { Phone } \\
\text { (Owned) }\end{array}$ & None \\
\hline 9 & 14 & M & $\begin{array}{l}\text { Housewife } \\
\text { Deceased }\end{array}$ & $\begin{array}{l}\text { Mother: Elementary } \\
\text { Graduate } \\
\text { Father: Elementary } \\
\text { Graduate }\end{array}$ & $\begin{array}{l}\text { Android } \\
\text { Phone } \\
\text { (Owned) }\end{array}$ & None \\
\hline
\end{tabular}

The researchers conducted face-to-face in-depth one-onone interview. The interview was recorded through android phone and were transcribed within a couple of days of occurrence. After which, participants reviewed, changed, and/or verified their comments.

Five distinct themes emerged from the research data. The major themes identified from the results of this study included:

(1) Modular distance learning is difficult.

(2) Modular distance learning resulted to poor learning outcome however there's a significant increase in grades

(3) Socio-economic status and unavailability of learning resources such as gadgets and internet connection resulted to unanswered module or incomplete academic requirements

(4) Having a More Knowledgeable Other make modular distance learning easier

(5) Having a social network and time-management eases the difficulties brought by modular distance learning

Theme 1 answered the number 2.1 research question; What are the respondents lived experiences in the new normal education in terms of Modular Distance Learning?
Theme 2 answered the number 2.2 research question What are the effects of new normal education to their academic performance? Theme 3 addressed the number 2.3 research question; What are the issues and challenges they encountered? Themes 4 and 5 answered the third research question; How do the respondents cope with their learning in the new normal education? Each theme is discussed in further detail below.

\section{Theme 1: Learning is Difficult}

All the participants pointed out that they experienced difficulty in answering the modules. The students were having a hard time understanding the contents of the modules particularly in Math, Science and English due to the absence of the teacher that will guide them and explain to them on what they are going to do. Moreover, the interview revealed that the language also serves as one of the barriers for having a better understanding of the modules. According to Bruner's theory of scaffolding, when children start to learn new concepts, they need help from teachers and other adults in the form of active support. He emphasized the social nature of learning, citing that other people should help a child develop skills through the process of scaffolding. The purpose of support is to allow the child to achieve higher levels of development by: simplifying the task or idea, motivating and encouraging the child, highlighting important task 
elements or errors and giving models that can be imitated (S. McLeod, 2019). The absence of the teacher in the teaching and learning process in Modular Distance Learning resulted to insufficient learning. However, participants claimed that it is fine because they have learned to learn on their own pace and as long as they have learned something amidst pandemic. Furthermore, due to the implementation of Modular Distance Learning, students are learning at home. Students tend to juggle household chores and studying. They prioritize house works, then they do their modules.

In addition, environmental factors also affect the difficulty of learning in Modular Distance Learning. Participants also claim that distractions from family members affect their learning. Consequently, they only make the module at night.

According to Hendrix (2019), learning environments play a crucial role in student success. Students learning in poor environments - those that are uncomfortable, loud, or full of distractions - will find it far more difficult to absorb information and stay engaged.

\section{Theme 2: Poor Learning Outcome}

Four out of Nine participants claimed that despite the insufficient and poor learning in Modular Distance Learning, there was still a significant increase of their grades compared to their Grade 7 which there was a faceto-face classes. However, five participants stressed that their grades in Grade 8 decreased compared to Grade 7 because of the difficulty they experienced in understanding and answering the module.

\section{Theme 3: Socio-Economic Status and Unavailability of Learning Resources}

According to Becker (1964) (cited by Li, Z., et. al., 2018), because of the limitation of family resources, parents of poor families usually are not able to invest sufficiently in their children's education, which affects their children's academic achievement. Most of the participants claimed that financial constraint and lack of learning devices limit their capability to comply academic requirements. Moreover, the socio-economic status and geographical location of the barangay affected the availability of learning resources. These limit the access to learning resources such as internet connection and learning facilities like library and computer shops.

\section{Theme 4: More Knowledgeable Other}

As discussed in Introduction, limited contact with teachers will place parents or guardians as the learners' model or the "More Knowledgeable Other" (MKO). Participants claimed that due to the difficulty in understanding the module, they seek help and guidance from a more knowledgeable other. Their older siblings serve as the MKO. However, participants only ask assistance on subjects that are too difficult for them such as Mathematics, Science, and English. Conversely, limited assistance is given to the participants for the reason that the MKO's also were doing their modules. However, due to the limited knowledge of the MKO's some parts of the module were left unanswered. The participants claimed that they only answer the parts they understood after exhausting their mental capacity. On the other hand, the participants seek assistance from each other, since they belong to one class.

\section{Theme 5: Social Network and Time-Management}

The interview revealed that the participants cope with their struggles through seeking support from others. Their responses showed that they often seek academic and social support from family and friends which lessen the burden of answering the modules.
According to Cherry (2020), it is social support that builds people up during times of stress and often gives them strength to carry on and even thrive. People can also provide what is known as informational support such as providing guidance, advice, information, and mentoring. By having this form of support, people may feel less anxious and stressed out about the problems they are trying to solve. In addition, based on the responses of the participants, it can be inferred that one of the ways students cope with studying in Modular Distance Learning and doing the household chores is time management. There were five out of nine participants who claimed that they balance their studies and household responsibilities through time management. Agreeing to Cyril (2015), time management can be very useful in a student's hectic schedule. It ensures that students are well-prepared, organized and focused to manage their daily lives and complete academic assignments on time. Effective time management improves the quality of life, as a whole. This is primarily because by managing the time, some of the most common problems such as stress and lack of time for personal interests can be solved very effortlessly.

\section{CONCLUSIONS}

The aim of this study was to describe the lived experiences of students in remotes areas in the new normal. Using a descriptive phenomenological approach and thematic data analysis, themes were formulated to provide an organization and explanation of the lived experiences of the participants.

Based on the findings of the study, the researcher comes to these conclusions:

(1) Majority of the students are 14 years old, belong to families with low level of income, and have android phone that serves as the only learning resource used in the Modular Distance Learning.

(2) The participants experienced difficulty in understanding the module due to the absence of the teacher to explain the contents of the module, inability to understand some of the difficult words or terminologies, doing household chores, learning environment, unavailability of learning resources, and poor internet connection.

(3) Majority of the participants had difficulty in understanding the module which resulted to low academic performance.

(4) The issues and challenges experienced by the majority of the participants are inability to comprehend and answering the module, scarcity of learning resources, financial constraint, and difficulty to comply the needed requirements.

(5) Majority of the students cope with their learning in the new normal through having a More Knowledgeable Others and time management.

\section{RECOMMENDATIONS}

Based on the findings and conclusions, these recommendations are given:

(1) The Department of Education, Schools, Local Government, and other stakeholders should work hand-in-hand to develop programs that will address the needs for learning resources of the students.

(2) Teachers should provide linguistic support to ensure that students will be able to understand the content of the modules.

(3) Teachers should conceptualize and simplify the lessons in the modules to enable the students to comprehend and to comply the needed requirements.

(4) Teachers should extend deadlines and allow students to submit missed works and resubmit work if there is a need to. 
(5) Teachers should keep in touch with the families and their students to be able to address the difficulties they encounter in modular distance learning.

(6) Parents and guardians should support their children emotionally, financially, morally, mentally and spiritually to ensure learners' well-being and to achieve better academic performance.

(7) This study serves as a springboard for further studies.

\section{REFERENCES}

[1] Cherry, K. (2020). How Social Support Contributes to Psychological Health. Retrieved from: https://www.verywllmind.com/social-support-forpsychological-health-4119970

[2] Dange, Y. R., \& Sumaoang, J. D. (2020). The Implementation of Modular Distance Learning in the Philippine Secondary Public Schools. Retrieved from: https://www.dpublication.com/wpcontent/uploads/2020/11/27-427.pdf

[3] De Villa, J., \& Manalo, F. K. (2020). Secondary Teachers' Preparation, Challenges, And Coping Mechanism in The Pre-Implementation of Distance Learning In The New Normal. Retrieved from: https://papers.ssrn.com/sol3/papers.cfm?abstract_ id $=3717608$

[4] Galanis, P. (2018). Data Analysis in Qualitative Research: Thematic Analysis. Retrieved from: https://www.researchgate.net/publication/325796 174_Data_analysis_in_qualitative_research_Themati c_analysis

[5] Hendrix, E. (2019). How Your Surroundings Affect the Way You Study. Retrieved from: https://www.ucas.com/connect/blogs/how-yoursorroundings-affect-way-you-study

[6] Li, Z., Qui, Z. (2018). How does Family background Affect Children's Educational Achievement? Evidence from Contemporary China. Retrieved from: https://doi.org/10.1186/s40711-018-0083-8

[7] Manlangit, P., Paglumotan, A. M., \& Saper. S. C., (2020). Nanay, Handa na ba Kayong Maging Tagpagdaloy: Superchanging Filipino Parents is Key for Successful Modular Distance Learning. Retrieved from: https://www.flipscience.ph/news/featuresnews/tagapagdaloy-modular-distance-learning/
[8] Owens, J., Hardcastle, L., \& Richardson, B. (2009). Learning from a Distance: The Experience of Remote Students. Retrieved from:

http://www.ijede.ca/index.php/jde/article/view/5 96/988

[9] McLeod, S. (2019). Bruner - Learning Theory in Education. Retrieved from https://www.simplypsychology.org/bruner.html

[10] Shi, Z. (2011). Dilemmas in Using Phenomenology to Investigate Elementary School Children Learning English as a Second Language. Retrieved from: https://ineducation.ca/ineducation/article/view/8 $8 / 372$

[11] Sumitra, P., \& Chhetri, R. (2021). A Literature Review on Impact of COVID-19 Pandemic on Teaching and Learning. Retrieved from:

https://www.researchgate.net/publication/348605 338_A_Literature_Review_on_Impact_of_COVID19_Pandemic_on_Teaching_and_Learning

[12] Wirihana, L., Welch, A., Williamson, M., Christensen, M., Bakon, S., \& Craft, J. (2018). Using Colaizzi's Method of Data Analysis to Explore the Experiences of Nurse Academics Teaching on Satellite Campuses. Retrieved from https://journals.rcni.com/nurse-researcher/usingcolaizzis-method-of-data-analysis-to-explore-theexperiences-of-nurse-academics-teaching-onsatellite-campuses-nr.2018.e1516

[13] From Equality to Global Poverty: The Covid-19 Effects on Societies and Economies (2020). Retrieved from: https://wellcome.org/news/equality-globalpoverty-how-covid-19-affecting-societies-andeconomies

[14] https://www.philatlas.com/visayas/r08/leyte/jaro /burabod.html

[15] https://www.questionpro.com/blog/distancelearning-survey-questions-for-students/

[16] https://www.psych.auckland.ac.nz/en/about/them atic-analysis.html\#top 